\title{
Sequential therapy involving an early switch from entecavir to pegylated interferon - $\alpha$ in Japanese patients with chronic hepatitis B
}

Masaru Enomoto, Shuhei Nishiguchi, Akihiro Tamori, Ritsuzo

Kozuka, Hideki Fujii, Sawako Uchida - Kobayashi, Shinya

Fukunishi, Yasuhiro Tsuda, Kazuhide Higuchi, Masaki Saito, Hirayuki Enomoto, Norifumi Kawada

\begin{tabular}{|c|l|}
\hline Citation & Hepatology Research, 48(6); 459-468 \\
\hline Issue Date & $2018-05$ \\
\hline Type & Journal Article \\
\hline Textversion & Author \\
\hline Rights & $\begin{array}{l}\text { This is the peer reviewed version of the following article: ENOMOTO M, et al. (2018). } \\
\text { Sequential therapy involving an early switch from entecavir to pegylated interferon-a in } \\
\text { Japanese patients with chronic hepatitis B. Hepatology Research: The Official Journal of } \\
\text { the Japan Society of Hepatology. 48, 459-468., which has been published in final form at } \\
\text { https://doi.org/10.1111/hepr.13050. This article may be used for non-commercial purposes } \\
\text { in accordance with Wiley Terms and Conditions for Self-Archiving. }\end{array}$ \\
\hline DOI & \begin{tabular}{l} 
10.1111/hepr.13050 \\
\hline
\end{tabular} \\
\hline
\end{tabular}

Self-Archiving by Author(s)

Placed on: Osaka City University

ENOMOTO M, et al. (2018). Sequential therapy involving an early switch from entecavir to pegylated interferon-a in Japanese patients with chronic hepatitis B. Hepatology Research: the Official Journal of the Japan Society of Hepatology. 48, 459-468. 


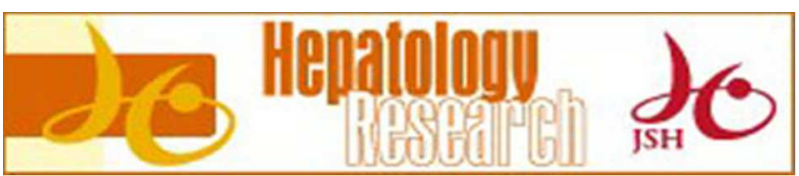

\section{Sequential therapy involving an early switch from entecavir to pegylated interferon-a in Japanese patients with chronic hepatitis B}

\begin{tabular}{|c|c|}
\hline Journal: & Hepatology Research \\
\hline Manuscript ID & HEPRES-17-0678.R1 \\
\hline Manuscript Type: & Original Article \\
\hline Date Submitted by the Author: & $\mathrm{n} / \mathrm{a}$ \\
\hline Complete List of Authors: & $\begin{array}{l}\text { Enomoto, Masaru; Osaka City University, Department of Hepatology; } \\
\text { Nishiguchi, Shuhei; Hyogo College of Medicine, Division of Hepatobiliary } \\
\text { and Pancreatic Medicine, Department of Internal Medicine } \\
\text { Tamori, Akihiro; Osaka City University Graduate School of Medicine, } \\
\text { Department of Hepatology } \\
\text { Kozuka, Ritsuzo; Graduate School of Medicine Osaka City University, } \\
\text { Department of Hepatology } \\
\text { Fujii, Hideki; Graduate School of Medicine Osaka City University, } \\
\text { Department of Hepatology; } \\
\text { Uchida-Kobayashi, Sawako; Graduate School of Medicine Osaka City } \\
\text { University, Department of Hepatology } \\
\text { Fukunishi, Shinya; Osaka Medical College, 2nd department of Internal } \\
\text { Medicaine } \\
\text { Tsuda, Yasuhiro; Osaka Medical College, The second Department of } \\
\text { Internal Medicine } \\
\text { Higuchi, Kazuhide; Osaka Medical College, The second Department of } \\
\text { Internal Medicine } \\
\text { Saito, Masaki } \\
\text { Enomoto, Hirayuki; Hyogo College of Medicine, ; } \\
\text { Kawada, Norifumi; Osaka City University, ; }\end{array}$ \\
\hline Category: & 7. Viral hepatitis \\
\hline
\end{tabular}




\section{Sequential therapy involving an early switch from entecavir to pegylated interferon- $\alpha$ in Japanese patients with chronic hepatitis B}

Masaru Enomoto, ${ }^{*}$ Shuhei Nishiguchi, ${ }^{2}$ Akihiro Tamori, ${ }^{1}$ Ritsuzo Kozuka, ${ }^{1}$ Hideki Fujii, ${ }^{1}$ Sawako Uchida-Kobayashi, ${ }^{1}$ Shinya Fukunishi, ${ }^{3}$ Yasuhiro Tsuda, ${ }^{3}$ Kazuhide Higuchi, ${ }^{3}$ Masaki Saito, ${ }^{2}$ Hirayuki Enomoto, ${ }^{2}$ Norifumi Kawada 1

${ }^{1}$ Department of Hepatology, Osaka City University Medical School, 1-4-3 Asahimachi, Abeno-ku, Osaka 545-8585, Japan; ${ }^{2}$ Department of Internal Medicine, Hyogo College of Medicine, Nishinomiya, Japan; and ${ }^{3}$ Second Department of Internal Medicine, Osaka Medical College, Osaka, Japan

*Correspondence to: Dr. Masaru Enomoto, Department of Hepatology, Graduate School of Medicine, Osaka City University Medical School, 1-4-3 Asahimachi, Abeno-ku, Osaka 545-8585, Japan.

E-mail: enomoto-m@med.osaka-cu.ac.jp

Running head: Sequential therapy with entecavir and PegIFN $\alpha$

Conflict of interest: S Nishiguchi has received research grants from Bristol-Myers K.K. and Chugai Pharmaceutical Co., Ltd. A Tamori has received research grants from Chugai Pharmaceutical Co., Ltd. N Kawada has received research grants from Bristol-Myers K.K. and Chugai Pharmaceutical Co., Ltd. 


\section{ABSTRACT}

Aim: The optimal combination of the two currently available agents with different mechanisms of action, a nucleos(t)ide analog and pegylated interferon- $\alpha$ (PegIFN $\alpha$ ), must be determined to improve treatment of chronic hepatitis B.

Methods: In this study, 24 patients with chronic hepatitis B (14 hepatitis B e-antigen [HBeAg]-positive and $10 \mathrm{HBeAg-negative)} \mathrm{received} \mathrm{entecavir} \mathrm{for} \mathrm{36-52} \mathrm{weeks,}$ followed by entecavir plus PegIFN $\alpha$-2a for 4 weeks and finally by PegIFNa-2a alone for 44 weeks.

Results: A sustained biochemical, virological, and serological response was obtained in 7/24 (29\%) patients at 48 weeks post-treatment (2/14 [14\%] in HBeAg-positive vs. 5/10 $[50 \%]$ in $\mathrm{HBeAg}$-negative patients, $P=0.085)$. At baseline, patients with a sustained response had a significantly lower $\gamma$-glutamyl transferase level $(P=0.0023)$, a lower aspartate aminotransferase-to-platelet ratio index $(P=0.049)$ and a lower $\alpha$-fetoprotein level $(P=0.042)$ than those without a sustained response. The decline in hepatitis B surface antigen (HBsAg) levels during the first 24 weeks of PegIFNa-2a treatment in patients with a sustained response was greater than that in patients without $(P=0.017)$. HBsAg seroclearance was achieved in two patients (8.3\%): one HBeAg-positive and one HBeAg-negative patient.

Conclusion: The outcomes of sequential therapy involving an early switch from entecavir to PegIFN $\alpha$-2a were unsatisfactory in Japanese patients with chronic hepatitis B. In addition to viral factors, host metabolic characteristics and liver fibrosis/tumor markers can be used for prediction of a sustained response to therapy, but accurate prediction of the therapeutic response is difficult.

Key words: Combination; genotype C; HBV; nucleoside analog; IFN 


\section{INTRODUCTION}

Hepatitis B virus (HBV) infection affects nearly 250 million people worldwide and is the major cause of end-stage liver disease, accounting for 780,000 deaths annually [1]. At present, available antiviral treatments for chronic hepatitis $\mathrm{B}$, nucleos(t)ide analogs and interferon- $\alpha$ (IFN $\alpha)$, can rarely eradicate HBV from infected hepatocytes [2-5]. Nucleos(t)ide analogs have little or no effect on the decrease in the intrahepatic HBV replicative intermediate, a covalently closed circular DNA. Although the immunomodulatory activity of IFN $\alpha$ can induce cytotoxic T-cell activity for clearance of infected cells, an adequate immune response against HBV is induced in only a minority of patients. More than 30 agents are currently under investigation in clinical trials [6], but at least several years will be required for approval of next-generation antiviral agents. Therefore, effective regimens comprising either simultaneous, add-on or sequential combination of the two currently available agents with different mechanisms of action are urgently needed in clinical practice [7-9].

Sequential therapy initiated with a nucleos(t)ide analog followed by IFN $\alpha$ has been evaluated. One objective of sequential therapy starting with a nucleos(t)ide analog is to lower the viral load, thereby restoring sensitivity to IFN $\alpha$ treatment. Another objective of sequential therapy is to prevent relapse of hepatitis after terminating the nucleos(t)ide analog through the use of IFN $\alpha$. The protocols varied among the studies; those switching to IFN $\alpha$ after the use of a nucleos(t)ide analog for about 1 year (referred to as early switch) might be aiming for the former goal [10-19], and those using a nucleos(t)ide analog for several years (referred to as late switch) the latter [20,21]. However, even among studies only of an early switch, the results were conflicting. This might be caused by differences in the included HBV genotypes, since HBV genotypes have specific geographic distributions and can affect the response to IFN $\alpha$ therapy $[22,23]$. The outcomes of sequential therapy have been unsatisfactory in Japanese 
studies (including ours) [24-28], at least in part because genotype C is the most prevalent type of $\mathrm{HBV}$, and is associated with a low likelihood of a favorable response to IFN $\alpha$ treatment.

In our previous studies [27,28], the rate of a sustained response to sequential therapy initiated with lamivudine or entecavir followed by IFN in Japanese, hepatitis B e-antigen (HBeAg)-positive patients was 21-29\%. Pegylation of IFNa improves its pharmacokinetic activity and prolongs its half-life. An international phase II study showed that once-weekly pegylated IFN $\alpha-2 \mathrm{a}(\mathrm{PegIFN} \alpha-2 \mathrm{a})$ resulted in a higher rate of sustained $\mathrm{HBe} A g$ seroconversion, HBV DNA suppression, and alanine aminotransferase (ALT) normalization than thrice-weekly non-pegylated IFN $\alpha-2 a$ (nonPegIFN $\alpha-2 a)$ for 24 weeks in HBeAg-positive patients (24\% vs. $12 \% ; P=0.036)$ [29]. In Japanese phase II and III registration studies, $90 \mu \mathrm{g}$ or $180 \mu \mathrm{g}$ PegIFNa-2a for 48 weeks produced a higher rate of a triple response than did nonPegIFN $\alpha$ for 24 weeks in HBeAg-positive and -negative patients with chronic hepatitis B (17.1-19.5\% vs. 7.0\%) [30]. Use of PegIFN $\alpha$ may therefore improve the outcome of sequential therapy starting with entecavir compared to use of nonPegIFNa. Although PegIFN $\alpha-2$ a use for 48 weeks was approved for both HBeAg-positive and -negative patients in Japan in 2011, the efficacy of sequential therapy with entecavir and PegIFNa-2a has not yet been reported.

In this study, we evaluated the efficacy of sequential therapy involving an early switch from entecavir to PegIFNa-2a in HBeAg-positive and -negative chronic hepatitis B patients in Japan. In addition, the clinical characteristics of patients with a sustained response to the sequential therapy were compared with those of patients without a sustained response. 


\section{METHODS}

\section{Patients}

This study included 24 Japanese patients with chronic hepatitis B (16 males and 8 females; mean age, $35 \pm 7$ years; $14 \mathrm{HBeAg-positive} \mathrm{and} 10 \mathrm{HBeAg}$-negative) who had received sequential therapy with entecavir followed by PegIFN $\alpha-2$ a between October 2010 and October 2013. The inclusion criteria were as follows: 1) persistent or fluctuating elevations of serum ALT levels for at least 6 months before the start of therapy; 2) presence of hepatitis B surface antigen (HBsAg) in serum; 3) presence of HBV DNA $>10^{4}$ copies $/ \mathrm{mL}$ (equivalent to $2,000 \mathrm{IU} / \mathrm{mL}$ ); 4) no use of corticosteroids or immunomodulatory drugs, including IFN, within 1 year before the start of therapy; 5) no use of nucleos(t)ide analogs, such as lamivudine, within 1 year before the start of therapy; 6) absence of resistance to nucleos(t)ide analogs; 7) absence of antibodies to hepatitis $\mathrm{C}$ virus and other likely causes of chronic liver disease; and 8) no clinical signs of decompensated cirrhosis or hepatocellular carcinoma. The procedures performed in this study were in accordance with the Helsinki Declaration of 1964 (2013 revision), and were approved by the ethics committee of each center. Written informed consent was obtained from each patient. This study was registered in the UMIN Clinical Trials Registry (registration ID number, UMIN000006943).

\section{Treatment}

Patients were treated with entecavir alone for 36 to 52 weeks, followed immediately by both entecavir and PegIFN $\alpha$-2a for 4 weeks and finally by PegIFN $\alpha-2 a$ alone for 44 weeks. Entecavir (Baraclude; Bristol-Myers K.K., Tokyo, Japan) was given orally at a dose of $0.5 \mathrm{mg}$, once daily. PegIFNa-2a (Pegasys, Chugai Pharmaceutical Co., Ltd., Tokyo, Japan) was given by subcutaneous injection at a dosage of $180 \mu \mathrm{g}$ 
once per week for 48 weeks. The dose of PegIFN $\alpha$-2a was modified because of adverse events in accordance with the manufacturers' recommendations. All patients were followed up for at least 48 weeks after completion of treatment, and responses to therapy were assessed as follows: a biochemical response was defined as a decrease in serum ALT levels to within the normal range; a virological response was defined as a decrease in serum HBV DNA to $<10^{4}$ copies $/ \mathrm{mL}$; and a serological response was defined as loss of serum HBeAg. A sustained response was defined as fulfillment of the criteria for biochemical, virological, and serological responses at 48 weeks after the end of therapy.

\section{Laboratory assays}

The following variables were determined for all enrolled patients: complete blood counts, serum aspartate aminotransferase (AST), ALT and $\gamma$-glutamyl transferase (GGT) activities, the Fibrosis-4 (FIB-4) index, AST-to-platelet ratio index (APRI), type IV collagen 7S, $\alpha$-fetoprotein, $\mathrm{HBsAg}, \mathrm{HBeAg}$, anti-HBe, hepatitis B core-related antigen (HBcrAg), HBV DNA levels, HBV genotype, and proportion of mutants in the precore and basal core promoter regions of HBV DNA.

Complete blood counts and serum AST, ALT and GGT activities were determined by standard procedures. The FIB-4 index was calculated using Sterling's formula: age $($ years $) \times \operatorname{AST}(\mathrm{IU} / \mathrm{L}) /$ platelet count $\left(\times 10^{9} / \mathrm{L}\right) \times \sqrt{ }$ ALT $\left.(\mathrm{IU} / \mathrm{L})\right)[31]$. The APRI score was

calculated using Wai's formula (AST/upper limit of normal)/platelet count (expressed as platelets $\left.\times 10^{9} / \mathrm{L}\right) \times 100$ [32]. Serum concentrations of type IV collagen 7S were measured by radioimmunoassay (Mitsubishi Kagaku Iatron Inc., Tokyo, Japan). Serum $\alpha$-fetoprotein levels were determined by chemiluminescence enzyme immunoassay. HBsAg was measured by chemiluminescent microparticle immunoassay (Architect HBsAg QT, Abbott Japan Corp., Tokyo, Japan) as described elsewhere [33]. HBeAg 
and anti-HBe were detected by chemiluminescence enzyme immunoassay. For quantitative evaluation of serum $\mathrm{HBeAg}$ levels, serial dilutions of the reference standard of PE HBeAg (Paul-Ehrlich Institute, Langen, Germany) were used to define the linear range of the assay and create a reference curve for linear regression, as described previously [34]. A standard curve was produced, and linear regression was used to convert assay results into appropriate units (PEIU/mL). HBcrAg was also detected by chemiluminescence enzyme immunoassay (Fuji-Rebio, Tokyo) [35]. HBV DNA was measured by real-time polymerase chain reaction assay (COBAS TaqMan HBV Test, ver. 2.0; Roche Diagnostics K.K., Tokyo, Japan) [36]. Genotypes of HBV were identified by enzyme-linked immunosorbent assay with monoclonal antibodies to type-specific epitopes in the preS2-region (Institute of Immunology, Tokyo, Japan) [37]. Mutations at nucleotide (nt) 1896 in the precore region and at $n t 1762$ and $n t 1764$ in the basal core promoter region of HBV DNA were identified by means of an enzyme-linked minisequence assay (Genome Science Laboratory, Tokyo, Japan).

\section{Histopathological evaluations}

When informed consent had been obtained, liver biopsy was performed before starting therapy. Histopathological findings were assessed by grading inflammatory activity and staging fibrosis according to the METAVIR scoring system [38]. An experienced pathologist blinded to the clinical data performed these evaluations.

\section{Statistical analysis}

Statistical analysis was conducted using JMP software (ver. 12.0; SAS Institute, Cary, NC, USA). Distributions of continuous variables were analyzed by the Mann-Whitney $U$ test. Differences in proportions were tested by Fisher's exact test. A two-tailed $P$-value of less than 0.05 was considered to indicate statistical significance. 


\section{RESULTS}

\section{Rate of response to therapy}

The proportions of patients with biochemical, virological, and serological responses at the start of PegIFN $\alpha$-2a therapy, at the end of PegIFN $\alpha$-2a therapy and at 48 weeks post-treatment, are shown in Figure 1. Overall, drug-resistant mutant variants did not emerge in any patient during entecavir treatment. At the start of PegIFN $\alpha-2 a$ treatment (about 1 year after the start of entecavir treatment), most patients had normal ALT levels and serum HBV DNA levels of $<10^{4}$ copies $/ \mathrm{mL}(92 \%$ and $100 \%$, respectively). However, serum ALT and HBV DNA levels increased in some patients during PegIFNa-2a treatment. Finally, at 24 and 48 weeks after completion of sequential therapy, a biochemical, virological, and serological response was obtained in $9(38 \%)$ and $7(29 \%)$ of the 24 patients, respectively.

At baseline, only $21 \%$ of $14 \mathrm{HBeAg}$-positive patients achieved $\mathrm{HBe} \mathrm{Ag}$ loss during entecavir treatment (Fig. 1B). During PegIFNa-2a treatment, HBeAg levels sometimes fell and the proportion of HBeAg-negative patients rose to $64 \%$, while HBV DNA sometimes rose and the proportion of patients with HBV DNA $<10^{4}$ copies $/ \mathrm{mL}$ fell from $100 \%$ to $57 \%$. Viral relapse also occurred after the end of treatment, and a combined response was achieved in $3(21 \%)$ and 2 (14\%) patients at 24 and 48 weeks after completion of sequential therapy, respectively. Hepatitis flare (defined as an increase in ALT level to 10-fold the upper limit of normal) occurred in one patient during PegIFN $\alpha$-2a treatment, and in another patient after the end of treatment. Peak ALT levels in these patients were 813 and 308 IU/L, respectively, but none had jaundice or decompensation.

A minority of $10 \mathrm{HBeAg}$-negative patients at baseline (Fig. 1C) exhibited reappearance of $\mathrm{HBeAg}$ and breakthrough in HBV DNA to $\geq 10^{4}$ copies $/ \mathrm{mL}$ during and after PegIFN $\alpha-2$ a treatment. A combined response was achieved in $6(60 \%)$ and $5(50 \%)$ 
of the patients at 24 and 48 weeks after completion of sequential therapy, respectively. The rate of sustained response in $\mathrm{HBeAg}$-negative patients was marginally higher than that in $\mathrm{HBeAg}$-positive patients $(2 / 14[14 \%]$ vs. $5 / 10$ [50\%], $P=0.085)$. Hepatitis flare did not occur in any HBeAg-negative patient.

\section{Baseline characteristics of patients according to response to therapy}

The baseline demographic, hematological, biochemical, virological, and histological characteristics of patients at the start of entecavir treatment are classified according to the response to sequential therapy in Table 1. At baseline, patients with a sustained response had significantly lower GGT $(P=0.0023)$, APRI $(P=0.049)$, and $\alpha$-fetoprotein $(P=0.042)$ levels than those without a sustained response. Marginal significance was found in the patients with a sustained response, with respect to lower ALT $(P=0.053)$ and type IV collagen 7S $(P=0.062)$ levels, a lower proportion of HBeAg-positive patients $(P=0.085)$ and a lower HBcrAg level $(P=0.086)$ than in those without a sustained response.

\section{On-treatment characteristics of patients according to response to therapy}

The on-treatment characteristics of the patients are shown according to the response to sequential therapy in Table 2. The change in HBcrAg levels during entecavir therapy $(P=0.024)$, and change in HBsAg levels during the first 24 weeks of PegIFN $\alpha$-2a therapy $(P=0.017)$, were significantly different between patients with and without a sustained response.

\section{Positive and negative predictive values of baseline factors for a therapeutic response}


We evaluated the positive and negative predictive values (PPV and NPV, respectively) of baseline factors for a sustained response to sequential therapy (Table 3). When the cut-off value was set at 27 IU/L GGT, the PPV and NPV for a sustained response were $76 \%$ and $86 \%$; when set at $2.8 \mathrm{ng} / \mathrm{mL}$ of $\alpha$-fetoprotein, the PPV and NPV were $58 \%$ and $89 \%$; when set at $3.4 \mathrm{ng} / \mathrm{mL}$ type IV collagen $7 \mathrm{~S}$, the PPV and NPV were $55 \%$ and $87 \%$; when set at 0.57 of APRI, the PPV and NPV were $81 \%$ and $78 \%$, respectively.

\section{Presentation of cases with HBsAg seroclearance}

As shown in Figure 2, seroclearance of HBsAg was achieved in two patients (8.3\%). The first was a 28-year-old, male, IFN-naïve, HBeAg-positive patient with genotype C infection. At baseline, his ALT activity was 43 IU/L, GGT 27 IU/L, APRI 0.35, type IV collagen 7S $2.7 \mathrm{ng} / \mathrm{mL}, \alpha$-fetoprotein $5.1 \mathrm{ng} / \mathrm{mL}, \mathrm{HBsAg}$ 19,118 IU/mL, HBeAg 794 PEIU/mL, HBcrAg $8.0 \log _{10} \mathrm{U} / \mathrm{mL}$ and HBV DNA $\geq 9.1 \log _{10}$ copies/mL. A liver biopsy specimen showed mild inflammation and mild fibrosis. The HBsAg level did not change significantly during entecavir and the first half of PegIFN $\alpha$-2a treatment, but decreased immediately after week 24 of PegIFNa-2a treatment and then became undetectable (Fig. 2A). The second was a 37-year-old, male, HBeAg-negative patient with genotype $\mathrm{C}$ infection who did not respond to a previous nonPegIFN $\alpha$ treatment. The baseline ALT activity was 63 IU/L, GGT 18 IU/L, APRI 0.45, type IV collagen 7S $4.5 \mathrm{ng} / \mathrm{mL}, \alpha$-fetoprotein $2.8 \mathrm{ng} / \mathrm{mL}, \mathrm{HBsAg} 902 \mathrm{IU} / \mathrm{mL}, \mathrm{HBcrAg} 2.9 \log _{10} \mathrm{U} / \mathrm{mL}$ and HBV DNA $5.0 \log _{10}$ copies/mL. A liver biopsy specimen showed mild inflammation and mild fibrosis. The HBsAg level did not change significantly during entecavir treatment, but decreased immediately after switching to PegIFN $\alpha-2 \mathrm{a}$ and then became undetectable (Fig. 2B). 


\section{DISCUSSION}

In this study, a sustained biochemical, virological, and serological response was achieved in 7 (29\%) of 24 Japanese patients with chronic hepatitis B at 48 weeks after completion of sequential therapy involving an early switch from entecavir to PegIFN $\alpha-2$ a (Fig. 1). When analyzed separately in $14 \mathrm{HBeAg-positive} \mathrm{and} 10$ $\mathrm{HBeAg}$-negative patients, the sustained response rate was $14 \%$ and $50 \%$, respectively. The response rate in $\mathrm{HBe} A g$-positive patients was lower than the rate in our previous study of sequential therapy with entecavir and nonPegIFN $\alpha$, which included only HBeAg-positive patients [28]; use of PegIFN $\alpha$ did not increase the rate of response to sequential therapy. The response rate in $\mathrm{HBeAg-negative} \mathrm{patients} \mathrm{was} \mathrm{higher} \mathrm{than} \mathrm{that}$ in $\mathrm{HBe} A g$-positive patients; therefore, $\mathrm{HBeAg-negative} \mathrm{patients} \mathrm{might} \mathrm{be} \mathrm{good}$ candidates for sequential therapy. Although the difference was not statistically significant (14\% vs. 50\%, $P=0.085), \mathrm{HBeAg}$ status is an important factor in determining a therapeutic response.

Next, we identified the baseline and on-treatment characteristics of patients showing a favorable response to sequential therapy (Table 1). The patients with a sustained response had a lower GGT level. In the case of hepatitis C, such metabolic factors could accelerate the progression of disease and impair the response to IFN $\alpha$ treatment [39], but its association in chronic hepatitis B has been investigated less extensively [40]. A large cohort study of Taiwanese men with chronic HBV infection aged 40-65 years associated a high burden of metabolic risk factors with increased risk of hepatocellular carcinoma [41]. In vitro studies showed that oxidative stress can impair the cellular response to IFN $\alpha$ via interference with Janus kinase/signal transducers and activators of the transcription pathway [42]. These metabolic factors could reduce the efficacy of PegIFN $\alpha$ therapy by the same mechanisms in patients with HCV. The APRI were lower in patients with than without a sustained response. In 
contrast, there were no significant differences between the two groups with respect to liver histopathology. The discrepancy may be caused by the majority of the patients having only mild inflammation and mild fibrosis in liver biopsy. Quantitative, noninvasive indices and markers can predict liver fibrosis more sensitively than semi-quantitative liver histology scoring.

Among viral markers, baseline HBeAg and HBcrAg levels in patients with a sustained response were lower than those in patients without a sustained response, albeit not significantly. Previous studies showed that low viral load was associated with an increased likelihood of a sustained response to IFN $\alpha$ [43,44]. The HBcrAg assay measures serum levels of all antigens transcribed from the pre-core/core gene - including a $22 \mathrm{kDa}$ precore protein and the hepatitis B core and e-antigens - by using monoclonal antibodies that recognize epitopes common to the denatured antigens $[35,45]$. By scoring the HBsAg and HBcrAg levels, as surrogate markers of covalently closed circular DNA in the liver, Matsumoto et al. [46] proposed a model for predicting relapse of hepatitis after discontinuation of nucleos(t)ide analog therapy.

Regarding on-treatment factors (Table 2), the decline in HBcrAg levels during entecavir therapy in patients with a sustained response was smaller than that in patients without a sustained response. This unexpected finding may be due to patients with a sustained response having a lower baseline HBcrAg level, and to the subsequent decrease being smaller than in patients without a sustained response. The decline in HBsAg levels during the first 24 weeks of PegIFN $\alpha-2$ a treatment in patients with a sustained response was greater than that in patients without a sustained response. This result is consistent with previous reports, showing that serum HBsAg drop in the first 24 weeks is useful for predicting the response to PegIFN $\alpha-2$ a treatment $[47,48]$. The treatment outcome could be predicted at an earlier stage using the HBsAg level at week 12 of PegIFN $\alpha-2$ a treatment [49,50]. Unfortunately, however, neither HBsAg level at week 12, nor HBsAg decline during the first 12 weeks of PegIFN $\alpha-2$ a treatment, was 
significantly predictive of a response to therapy in this study. Two patients achieved HBsAg seroclearance, which is the ultimate goal in treatment of chronic hepatitis B. In one patient, the HBsAg level was unchanged during entecavir therapy and then declined steeply in the first quarter of PegIFN $\alpha$-2a treatment, and in the second half in the other patient (Fig. 2).

For prediction of a sustained response to sequential therapy by baseline factors (Table 3), serum HBcrAg and HBeAg levels could identify patients who are unlikely to respond to treatment (NPVs of $89 \%$ and $78 \%$, respectively). In addition to viral factors, host factors, including GGT, $\alpha$-fetoprotein and type IV collagen 7S levels, as well as APRI, in patients with a sustained response were different from those in patients without. However, of the two patients with $\mathrm{HBsAg}$ seroclearance, one HBeAg-positive patient had HBcrAg $\geq 5.0 \log _{10} \mathrm{U} / \mathrm{mL}$ and $\alpha$-fetoprotein level $>2.8 \mathrm{ng} / \mathrm{mL}$ in serum, and the other $\mathrm{HBeAg}$-negative patient had a type IV collagen $7 \mathrm{~S}$ level of $\geq 3.5 \mathrm{ng} / \mathrm{mL}$. Therefore, accurate prediction of the outcome of sequential therapy is difficult.

The JSH Guidelines [5] suggest that Peg-IFN monotherapy should be considered the first choice treatment for chronic hepatitis, irrespective of $\mathrm{HBeAg}$ status or $\mathrm{HBV}$ genotype. Retreatment using Peg-IFN should be considered in patients with chronic hepatitis when recurrence of hepatitis occurs following treatment with conventional IFN or Peg-IFN. However, at the time of a hepatitis flare, IFN is generally contraindicated because of concerns regarding decompensation. The use of entecavir before induction of PegIFNa in sequential therapy involving an early switch can be recommended in patients following a hepatitis flare. Sequential therapy involving an early switch can also be considered for treatment-experienced patients, to enhance the therapeutic efficacy by lowering the viral load, thereby restoring treatment sensitivity. However, evidence is still lacking.

This study had several limitations. First, this study was not a controlled trial. In Japanese phase II and III studies of 90 or $180 \mu \mathrm{g}$ PegIFN $\alpha$-2a monotherapy, the rate of a 
sustained triple response (17.1-19.5\% in 48-week treatment arms) was lower than that in this study [30]. However, we cannot conclude that short-term use of entecavir enhanced the effectiveness of PegIFN $\alpha-2 \mathrm{a}$ treatment, because of differences in patient backgrounds and treatment response definitions between the two studies. Second, we defined a sustained response as a triple response at 48 weeks post-treatment. However, relapse beyond 48 weeks post-treatment was not rare in our previous study in the long-term [51].

In conclusion, the outcomes of sequential therapy involving an early switch from entecavir to PegIFN $\alpha$-2a were unsatisfactory in Japanese patients with chronic hepatitis B. In general, HBeAg-negative patients are good candidates for sequential therapy, but $\mathrm{HBeAg-positive} \mathrm{patients} \mathrm{can} \mathrm{also} \mathrm{achieve} \mathrm{HBsAg} \mathrm{seroclearance.} \mathrm{In} \mathrm{addition} \mathrm{to} \mathrm{viral}$ factors, host metabolic factors and liver fibrosis/tumor markers can be used for prediction of a sustained response to therapy, but accurate prediction of the outcome of sequential therapy using baseline factors is difficult. 


\section{ACKNOWLEDGEMENTS}

The authors are grateful to Ms. Yoko Yasuhara, Ms. Sanae Deguchi, and Ms.

Tomoko Hirano for their technical assistance. This research was supported in part by the Program for Basic and Clinical Research on Hepatitis of the Japan Agency for Medical Research and Development, AMED. 


\section{REFERENCES}

1. Trépo C, Chan HL, Lok A. Hepatitis B virus infection. Lancet. 2014; 384: 2053-63.

2. Terrault NA, Bzowej NH, Chang KM, Hwang JP, Jonas MM, Murad MH; American Association for the Study of Liver Diseases. AASLD guidelines for treatment of chronic hepatitis B. Hepatology. 2016; 63: 261-83.

3. European Association for the Study of the Liver. EASL 2017 Clinical Practice Guidelines on the management of hepatitis B virus infection. J Hepatol. 2017; 67: $370-98$.

4. Sarin SK, Kumar M, Lau GK, et al. Asian-Pacific clinical practice guidelines on the management of hepatitis B: a 2015 update. Hepatol Int. 2016; 10: 1-98.

5. Drafting Committee for Hepatitis Management Guidelines and the Japan Society of Hepatology. JSH Guidelines for the Management of Hepatitis B Virus Infection. Hepatol Res. 2014; 44 Supp1 S1: 1-58.

6. Brahmania M, Feld J, Arif A, Janssen HL. New therapeutic agents for chronic hepatitis B. Lancet Infect Dis. 2016; 16: e10-21.

7. Enomoto M, Tamori A, Nishiguchi S, Kawada N. Combination therapy with a nucleos(t)ide analogue and interferon for chronic hepatitis B: simultaneous or sequential. J Gastroenterol. 2013; 48: 999-1005.

8. Petersen J, Dandri M. Optimal therapy for chronic hepatitis B: hepatitis B virus combination therapy? Liver Int. 2015; 35 Suppl 1: 114-20.

9. Viganò M, Invernizzi F, Grossi G, Lampertico P. Review article: the potential of interferon and nucleos $(\mathrm{t})$ ide analogue combination therapy in chronic hepatitis B infection. Aliment Pharmacol Ther. 2016; 44: 653-61.

10. Serfaty L, Thabut D, Zoulim F, et al. Sequential treatment with lamivudine and interferon monotherapies in patients with chronic hepatitis B not responding to interferon alone: results of a pilot study. Hepatology. 2001; 34: 573-7.

11. Sarin SK, Sood A, Kumar M, et al.; National Collaborative Group on Hepatitis B, 
India. Effect of lowering HBV DNA levels by initial antiviral therapy before adding immunomodulator on treatment of chronic hepatitis B. Am J Gastroenterol. 2007; 102: $96-104$.

12. Manesis EK, Papatheodoridis GV, Hadziyannis SJ. A partially overlapping treatment course with lamivudine and interferon in hepatitis B e antigen-negative chronic hepatitis B. Aliment Pharmacol Ther. 2006; 23: 99-106.

13. Vassiliadis T, Tziomalos K, Patsiaoura K, et al. Lamivudine/pegylated interferon alfa-2b sequential combination therapy compared with lamivudine monotherapy in HBeAg-negative chronic hepatitis B. J Gastroenterol Hepatol. 2007; 22: 1582-8.

14. Shi M, Wang RS, Zhang H, et al. Sequential treatment with lamivudine and interferon-alpha monotherapies in hepatitis B e antigen-negative Chinese patients and its suppression of lamivudine-resistant mutations. J Antimicrob Chemother. 2006; 58: 1031-5.

15. Moucari R, Boyer N, Ripault MP, et al. Sequential therapy with adefovir dipivoxil and pegylated interferon alfa-2a for HBeAg-negative patients. J Viral Hepat. 2011; 18: $580-6$.

16. Chen CC, Wang PC, Chang HW, Chen CF. Safety and efficacy of two-step peginterferon $\alpha$-2a treatment in patients of chronic hepatitis B with acute exacerbation. J Viral Hepat. 2012; 19: 161-72.

17. Boglione L, D'Avolio A, Cariti G, et al. Sequential therapy with entecavir and PEG-INF in patients affected by chronic hepatitis B and high levels of HBV-DNA with non-D genotypes. $J$ Viral Hepat. 2013; 20: e11-9.

18. Xie Q, Zhou H, Bai X, et al. A randomized, open-label clinical study of combined pegylated interferon Alfa-2a (40KD) and entecavir treatment for hepatitis B "e" antigen-positive chronic hepatitis B. Clin Infect Dis. 2014; 59: 1714-23.

19. Boglione L, Cariti G, Di Perri G, D'Avolio A. Sequential therapy with entecavir and pegylated interferon in a cohort of young patients affected by chronic hepatitis B. $J$ 
Med Virol. 2016; 88: 1953-9.

20. Ning Q, Han M, Sun Y, et al. Switching from entecavir to PegIFN alfa-2a in patients with $\mathrm{HBeAg}$-positive chronic hepatitis B: a randomised open-label trial (OSST trial). J Hepatol. 2014; 61: 777-84.

21. He LT, Ye XG, Zhou XY. Effect of switching from treatment with nucleos(t)ide analogs to pegylated interferon $\alpha-2 \mathrm{a}$ on virological and serological responses in chronic hepatitis B patients. World J Gastroenterol. 2016; 22: 10210-10218.

22. Orito E, Ichida T, Sakugawa H, et al. Geographic distribution of hepatitis B virus (HBV) genotype in patients with chronic HBV infection in Japan. Hepatology. 2001; 34: 590-4.

23. Enomoto M, Tamori A, Nishiguchi S. Hepatitis B virus genotypes and response to antiviral therapy. Clin Lab. 2006; 52: 43-7.

24. Okuse C, Yotsuyanagi H, Yamada N, et al. Effect of nucleoside analog-interferon sequential therapy on patients with acute exacerbation of chronic hepatitis B. Hepatol Res. 2010; 40: 461-9.

25. Matsumoto A, Yatsuhashi H, Nagaoka S, et al. Factors associated with the effect of interferon- $\alpha$ sequential therapy in order to discontinue nucleoside/nucleotide analog treatment in patients with chronic hepatitis B. Hepatol Res. 2015; 45: 1195-202.

26. Matsumoto A, Nishiguchi S, Enomoto H, et al. Combinational use of hepatitis B viral antigens predicts responses to nucleos(t)ide analogue/peg-interferon sequential therapy. J Gastroenterol. 2017 Jun 20. doi:10.1007/s00535-017-1360-z.

27. Enomoto M, Tamori A, Kohmoto MT, et al. Lamivudine and IFN-beta sequential therapy in $\mathrm{HBe}$ antigen-positive patients with chronic hepatitis $\mathrm{B}$ virus genotype $\mathrm{C}$ infection. J Interferon Cytokine Res. 2007; 27: 201-7.

28. Enomoto M, Nishiguchi S, Tamori A, et al. Entecavir and interferon- $\alpha$ sequential therapy in Japanese patients with hepatitis B e antigen-positive chronic hepatitis B. $J$ Gastroenterol. 2013; 48: 397-404. 
29. Cooksley WG, Piratvisuth T, Lee SD, et al. Peginterferon alpha-2a (40 kDa): an advance in the treatment of hepatitis B e antigen-positive chronic hepatitis B. J Viral Hepat. 2003; 10: 298-305.

30. Okanoue T, Shima T, Hasebe C, et al. Long-term follow up of peginterferon- $\alpha-2 \mathrm{a}$ treatment of hepatitis $\mathrm{B}$ e-antigen $(\mathrm{HBeAg})$ positive and $\mathrm{HBe} A g$ negative chronic hepatitis B patients in phase II and III studies. Hepatol Res. 2016; 46: 992-1001.

31. Sterling RK, Lissen E, Clumeck N, et al.; APRICOT Clinical Investigators. Development of a simple noninvasive index to predict significant fibrosis in patients with HIV/HCV coinfection. Hepatology. 2006; 43: 1317-25.

32. Wai CT, Greenson JK, Fontana RJ, et al. A simple noninvasive index can predict both significant fibrosis and cirrhosis in patients with chronic hepatitis $\mathrm{C}$. Hepatology. 2003; 38: 518-26.

33. Kohmoto M, Enomoto M, Tamori A, et al. Quantitative detection of hepatitis B surface antigen by chemiluminescent microparticle immunoassay during lamivudine treatment of chronic hepatitis B virus carriers. J Med Virol. 2005; 75: 235-9.

34. Bae SK, Yatsuhashi H, Hashimoto S, et al. Prediction of early HBeAg seroconversion by decreased titers of $\mathrm{HBeAg}$ in the serum combined with increased grades of lobular inflammation in the liver. Med Sci Monit. 2012; 18: CR698-705.

35. Kimura T, Rokuhara A, Sakamoto Y, et al. Sensitive enzyme immunoassay for hepatitis B virus core-related antigens and their correlation to virus load. J Clin Microbiol. 2002; 40: 439-45.

36. Hochberger S, Althof D, Gallegos de Schrott R, Nachbaur N, Röck H, Leying H. Fully automated quantitation of hepatitis B virus (HBV) DNA in human plasma by the COBAS AmpliPrep/COBAS TaqMan system. J Clin Virol. 2006; 35: 373-80.

37. Usuda S, Okamoto H, Iwanari H, et al. Serological detection of hepatitis B virus genotypes by ELISA with monoclonal antibodies to type-specific epitopes in the preS2-region product. J Virol Methods. 1999; 80: 97-112. 
38. Bedossa P, Poynard T. An algorithm for the grading of activity in chronic hepatitis C. The METAVIR Cooperative Study Group. Hepatology. 1996; 24: 289-93.

39. Lonardo A, Adinolfi LE, Restivo L, et al. Pathogenesis and significance of hepatitis C virus steatosis: an update on survival strategy of a successful pathogen. World $J$ Gastroenterol. 2014; 20: 7089-103.

40. Jarcuska P, Drazilova S, Fedacko J, Pella D, Janicko M. Association between hepatitis B and metabolic syndrome: Current state of the art. World J Gastroenterol. $2016 ; 22: 155-64$.

41. Yu MW, Lin CL, Liu CJ, Yang SH, Tseng YL, Wu CF. Influence of Metabolic Risk Factors on Risk of Hepatocellular Carcinoma and Liver-related Death in Men with Chronic Hepatitis B: A Large Cohort Study. Gastroenterology. 2017 Jul 12. pii: S0016-5085(17)35866-3.

42. Di Bona D, Cippitelli M, Fionda C, et al. Oxidative stress inhibits IFN-alpha-induced antiviral gene expression by blocking the JAK-STAT pathway. $J$ Hepatol. 2006; 45: 271-9.

43. Buster EH, Hansen BE, Lau GK, et al. Factors that predict response of patients with hepatitis B e antigen-positive chronic hepatitis B to peginterferon-alfa. Gastroenterology. 2009; 137: 2002-9.

44. Bonino F, Marcellin P, Lau GK, et al.; Peginterferon Alfa-2a HBeAg-Negative Chronic Hepatitis B Study Group. Predicting response to peginterferon alpha-2a, lamivudine and the two combined for HBeAg-negative chronic hepatitis B. Gut. 2007; 56: 699-705.

45. Rokuhara A, Tanaka E, Matsumoto A, et al. Clinical evaluation of a new enzyme immunoassay for hepatitis B virus core-related antigen; a marker distinct from viral DNA for monitoring lamivudine treatment. J Viral Hepat. 2003; 10: 324-30.

46. Matsumoto A, Tanaka E, Suzuki Y, et al. Combination of hepatitis B viral antigens and DNA for prediction of relapse after discontinuation of nucleos(t)ide analogs in 
patients with chronic hepatitis B. Hepatol Res. 2012; 42: 139-49.

47. Moucari R, Mackiewicz V, Lada O, et al. Early serum HBsAg drop: a strong predictor of sustained virological response to pegylated interferon alfa-2a in HBeAg-negative patients. Hepatology. 2009; 49: 1151-7.

48. Chan HL, Wong VW, Chim AM, et al. Serum HBsAg quantification to predict response to peginterferon therapy of e antigen positive chronic hepatitis B. Aliment Pharmacol Ther. 2010; 32: 1323-31.

49. Sonneveld MJ, Rijckborst V, Boucher CA, Hansen BE, Janssen HL. Prediction of sustained response to peginterferon alfa- $2 \mathrm{~b}$ for hepatitis $\mathrm{B}$ e antigen-positive chronic hepatitis B using on-treatment hepatitis B surface antigen decline. Hepatology. 2010; 52: 1251-7.

50. Rijckborst V, Hansen BE, Cakaloglu Y, et al. Early on-treatment prediction of response to peginterferon alfa-2a for $\mathrm{HBe} A g$-negative chronic hepatitis B using HBsAg and HBV DNA levels. Hepatology. 2010; 52: 454-61.

51. Enomoto M, Nishiguchi S, Tamori A, et al. Long-Term Outcome of Sequential Therapy with Lamivudine Followed by Interferon- $\beta$ in Nucleoside-Naive, Hepatitis B e-Antigen-Positive Patients with Chronic Hepatitis B Virus Genotype C Infection. J Interferon Cytokine Res. 2015; 35: 613-20. 
Table 1 Baseline characteristics of patients according to response to therapy

\begin{tabular}{|c|c|c|c|}
\hline Variable & $\begin{array}{l}\text { Sustained responders } \\
\qquad(\mathrm{n}=7)\end{array}$ & $\begin{array}{l}\text { Non-responders } \\
\qquad(\mathrm{n}=17) \\
\end{array}$ & $\begin{array}{l}P \\
\text { value }\end{array}$ \\
\hline Age (years) $b$ & $34 \pm 11$ & $36 \pm 6$ & 0.14 \\
\hline Female gender ${ }^{a}$ & $4(57 \%)$ & $4(24 \%)$ & 0.17 \\
\hline Body mass index $b$ & $21.5 \pm 2.6$ & $23.9 \pm 3.6$ & 0.13 \\
\hline Previous interferon history a & $4(57 \%)$ & $10(59 \%)$ & 0.99 \\
\hline $\operatorname{ALT}(\mathrm{IU} / \mathrm{L})^{\mathrm{c}}$ & $43(15,63)$ & $119(35,783)$ & 0.053 \\
\hline GGT (IU/L) ${ }^{\mathrm{c}}$ & $18(14,27)$ & $58(28,131)$ & 0.0023 \\
\hline Platelet $\left(\times 10^{3} / \mu \mathrm{L}\right)^{\mathrm{b}}$ & $193 \pm 16$ & $199 \pm 63$ & 0.85 \\
\hline FIB-4 index ${ }^{c}$ & $0.82(0.63,1.03)$ & $1.12(0.75,2.05)$ & 0.11 \\
\hline $\mathrm{APRI}^{\mathrm{c}}$ & $0.45(0.37,0.57)$ & $0.89(0.46,3.45)$ & 0.049 \\
\hline Type IV collagen $7 \mathrm{~S}(\mathrm{ng} / \mathrm{mL}) \mathrm{c}$ & $3.3(2.7,4.6)$ & $4.3(3.6,7.6)$ & 0.062 \\
\hline$\alpha$-fetoprotein $(\mathrm{ng} / \mathrm{mL}) \mathrm{c}$ & $2.2(1.9,4.6)$ & $3.6(3.0,14.1)$ & 0.042 \\
\hline HBsAg $\left(\log _{10} \mathrm{IU} / \mathrm{mL}\right)^{b}$ & $3.80 \pm 0.76$ & $3.72 \pm 0.69$ & 0.78 \\
\hline Qualitative HBeAg-positive ${ }^{\text {a }}$ & $2(29 \%)$ & $12(71 \%)$ & 0.085 \\
\hline Quantitative $\mathrm{HBeAg}(\mathrm{PEIU} / \mathrm{mL}){ }^{\mathrm{c}}$ & $<0.15(<0.15,794)$ & $120(<0.15,891)$ & 0.31 \\
\hline $\operatorname{HBcrAg}\left(\log _{10} \mathrm{U} / \mathrm{mL}\right)^{b}$ & $5.1 \pm 2.4$ & $6.9 \pm 1.9$ & 0.086 \\
\hline HBV DNA $\left(\log _{10} \text { copies } / \mathrm{mL}\right)^{b}$ & $6.0 \pm 2.6$ & $7.9 \pm 1.6$ & 0.14 \\
\hline HBV genotype C a & $7(100 \%)$ & $16(94 \%)$ & 0.99 \\
\hline Precore G1896A a & $5(71 \%)$ & $6(35 \%)$ & 0.22 \\
\hline $\begin{array}{l}\text { Basic core promoter } \\
\text { A1762T/G1764A }\end{array}$ & $2(29 \%)$ & $5(29 \%)$ & 0.95 \\
\hline Grade of inflammation (A1/A2/A3) a & $6 / 0 / 0$ & $12 / 3 / 1$ & 0.40 \\
\hline Stage of fibrosis $(\mathrm{F} 1 / \mathrm{F} 2 / \mathrm{F} 3)^{\mathrm{a}}$ & $6 / 0 / 0$ & $12 / 3 / 1$ & 0.40 \\
\hline
\end{tabular}

aNumbers of patients; ${ }^{b}$ Mean $\pm \mathrm{SD}$; ${ }^{c}$ Median (interquartile range).

ALT, alanine aminotransferase; APRI, aspartate aminotransferase-to-platelet ratio index; FIB-4, Fibrosis-4; GGT, $\gamma$-glutamyl transferase; HBcrAg, hepatitis B core-related antigen; HBeAg, hepatitis B e antigen; HBsAg, hepatitis B surface antigen; HBV, hepatitis B virus 
Table 2 On-treatment characteristics of patients according to response to therapy

\begin{tabular}{|c|c|c|c|}
\hline Variable & $\begin{array}{l}\text { Sustained responders } \\
\qquad(\mathrm{n}=7) \\
\end{array}$ & $\begin{array}{l}\text { Non-responders } \\
\qquad(\mathrm{n}=17) \\
\end{array}$ & $P$ value \\
\hline \multicolumn{4}{|l|}{ At the start of PegIFNa-2a } \\
\hline $\operatorname{ALT}(\mathrm{IU} / \mathrm{L})^{\mathrm{c}}$ & $22(9,28)$ & $20(13,27)$ & 0.61 \\
\hline Platelet $\left(\times 10^{3} / \mu \mathrm{L}\right)^{b}$ & $202 \pm 13$ & $217 \pm 67$ & 0.24 \\
\hline $\mathrm{HBsAg}\left(\log _{10} \mathrm{IU} / \mathrm{mL}\right)^{b}$ & $3.53 \pm 0.59$ & $3.52 \pm 0.65$ & 0.95 \\
\hline Qualitative HBeAg-positive ${ }^{\mathrm{a}}$ & $2(29 \%)$ & $10(59 \%)$ & 0.37 \\
\hline Quantitative HBeAg (PEIU/mL) $\mathrm{c}$ & $<0.15(<0.15,38.0)$ & $0.23(<0.15,20.4)$ & 0.45 \\
\hline $\operatorname{HBcrAg}\left(\log _{10} \mathrm{U} / \mathrm{mL}\right)^{\mathrm{b}}$ & $4.7 \pm 1.9$ & $5.2 \pm 1.6$ & 0.39 \\
\hline HBV DNA $\left(\log _{10} \text { copies } / \mathrm{mL}\right)^{\mathrm{c}}$ & $<2.1(<2.1,<2.1)$ & $<2.1(<2.1,2.3)$ & 0.31 \\
\hline \multicolumn{4}{|l|}{ At week 12 of PegIFNa-2a } \\
\hline $\operatorname{HBsAg}\left(\log _{10} \mathrm{IU} / \mathrm{mL}\right)^{b}$ & $3.09 \pm 1.19$ & $3.45 \pm 0.62$ & 0.63 \\
\hline Qualitative HBeAg-positive a & $2(29 \%)$ & $6(35 \%)$ & 0.99 \\
\hline Quantitative HBeAg $(\mathrm{PEIU} / \mathrm{mL})^{\mathrm{c}}$ & $<0.15(<0.15,6.03)$ & $<0.15(<0.15,5.37)$ & 0.90 \\
\hline $\operatorname{HBcrAg}\left(\log _{10} \mathrm{U} / \mathrm{mL}\right)^{\mathrm{b}}$ & $4.6 \pm 1.8$ & $5.1 \pm 1.5$ & 0.36 \\
\hline \multicolumn{4}{|l|}{ At week 24 of PegIFNa-2a } \\
\hline HBsAg $\left(\log _{10} I U / m L\right) b$ & $2.61 \pm 1.87$ & $3.38 \pm 0.81$ & 0.43 \\
\hline \multicolumn{4}{|l|}{ During entecavir therapy } \\
\hline Changes in HBsAg $\left(\log _{10} \mathrm{IU} / \mathrm{mL}\right)^{\mathrm{c}}$ & $-0.06(-0.35,0.01)$ & $-0.03(-0.43,0.09)$ & 0.78 \\
\hline Changes in HBcrAg $\left(\log _{10} \mathrm{U} / \mathrm{mL}\right)^{\mathrm{c}}$ & $-0.1(-0.6,0.0)$ & $-1.6(-2.1,-0.5)$ & 0.024 \\
\hline \multicolumn{4}{|c|}{ During the first 12 weeks of PegIFNa-2a therapy } \\
\hline Changes in HBsAg $\left(\log _{10} \mathrm{IU} / \mathrm{mL}\right)^{\mathrm{c}}$ & $-0.31(-0.39,-0.02)$ & $-0.08(-0.17,0.09)$ & 0.081 \\
\hline Changes in $\mathrm{HBcrAg}\left(\log _{10} \mathrm{U} / \mathrm{mL}\right)^{\mathrm{c}}$ & $0.0(-0.1,0.0)$ & $-0.1(-0.3,0.0)$ & 0.27 \\
\hline \multicolumn{4}{|c|}{ During the first 24 weeks of PegIFNo-2a therapy } \\
\hline Changes in HBsAg $\left(\log _{10} \mathrm{IU} / \mathrm{mL}\right)^{\mathrm{c}}$ & $-0.49(-0.65,-0.22)$ & $-0.08(-0.31,0.10)$ & 0.017 \\
\hline \multicolumn{4}{|c|}{ During 48 weeks of PegIFNa-2a therapy } \\
\hline Peak ALT (IU/L) ${ }^{\mathrm{c}}$ & $36(30,84)$ & $53(37,80)$ & 0.73 \\
\hline
\end{tabular}

aNumber of patients; ${ }^{b}$ Mean $\pm \mathrm{SD}$; ${ }^{c}$ Median (interquartile range).

ALT, alanine aminotransferase; HBcrAg, hepatitis B core-related antigen; $\mathrm{HBeAg}$, hepatitis B e antigen; HBsAg, hepatitis B surface antigen; HBV, hepatitis B virus 
Table 3 Positive and negative predictive values of baseline factors for a therapeutic response

\begin{tabular}{|c|c|c|c|c|c|c|}
\hline & Cut-off & Sensitivity (\%) & Sensitivity (\%) & PPV (\%) & NPV (\%) & AUROC \\
\hline GGT & $27 \mathrm{IU} / \mathrm{L}$ & 76 & 76 & 76 & 86 & 0.90 \\
\hline$\alpha$-fetoprotein & $2.8 \mathrm{ng} / \mathrm{mL}$ & 82 & 82 & 58 & 89 & 0.77 \\
\hline Type IV collagen 7S & $3.4 \mathrm{ng} / \mathrm{mL}$ & 80 & 80 & 55 & 87 & 0.77 \\
\hline APRI & 0.57 & 71 & 71 & 81 & 78 & 0.76 \\
\hline ALT & $50 \mathrm{IU} / \mathrm{L}$ & 71 & 71 & 64 & 77 & 0.76 \\
\hline Baseline HBcrAg & $4.9 \log _{10} \mathrm{U} / \mathrm{mL}$ & 82 & 82 & 59 & 89 & 0.73 \\
\hline Baseline $\mathrm{HBeAg}$ & positive & 72 & 72 & 69 & 78 & 0.71 \\
\hline
\end{tabular}

ALT, alanine aminotransferase; APRI, aspartate aminotransferase-to-platelet ratio index; AUROC, area under the receiver operating characteristic curve; GGT, $\gamma$-glutamyl transferase; HBcrAg, hepatitis B core-related antigen; HBeAg, hepatitis B e antigen; NPV, negative predictive value; PPV, positive predictive value 


\section{Figure Legends}

Fig. 1 Rates of biochemical, virological and serological responses during and after sequential therapy starting with entecavir followed by pegylated interferon- $\alpha 2 a$ (PegIFNa-2a) (A) in 24 patients with chronic hepatitis B comprising (B) 14 hepatitis B e-antigen (HBeAg)-positive patients and (C) $10 \mathrm{HBeAg-negative} \mathrm{patients.}$

Fig. 2 Changes in alanine aminotransferase, hepatitis B surface antigen (HBsAg), and hepatitis B virus (HBV) DNA levels in two patients who achieved HBsAg seroclearance.

(A) The first was a 28-year-old, male, treatment-naïve, hepatitis B e-antigen (HBeAg)-positive patient with genotype $\mathrm{C}$ infection. The HBsAg level did not change significantly during entecavir and the first half of pegylated interferon- $\alpha 2 a$ (PegIFN $\alpha-2 a)$ treatment, but decreased immediately after week 24 of PegIFN $\alpha-2 a$ treatment, and then became undetectable. (B) The second was a 37-year-old, male, HBeAg-negative patient with genotype $\mathrm{C}$ infection who did not respond to a previous nonPegIFN $\alpha$ treatment. The HBsAg level did not change significantly during entecavir treatment, but decreased immediately after switching to PegIFNa-2a, and then became undetectable. The broken line indicates the lower limit of quantification of HBV DNA (2.1 $\log _{10}$ copies/mL). 







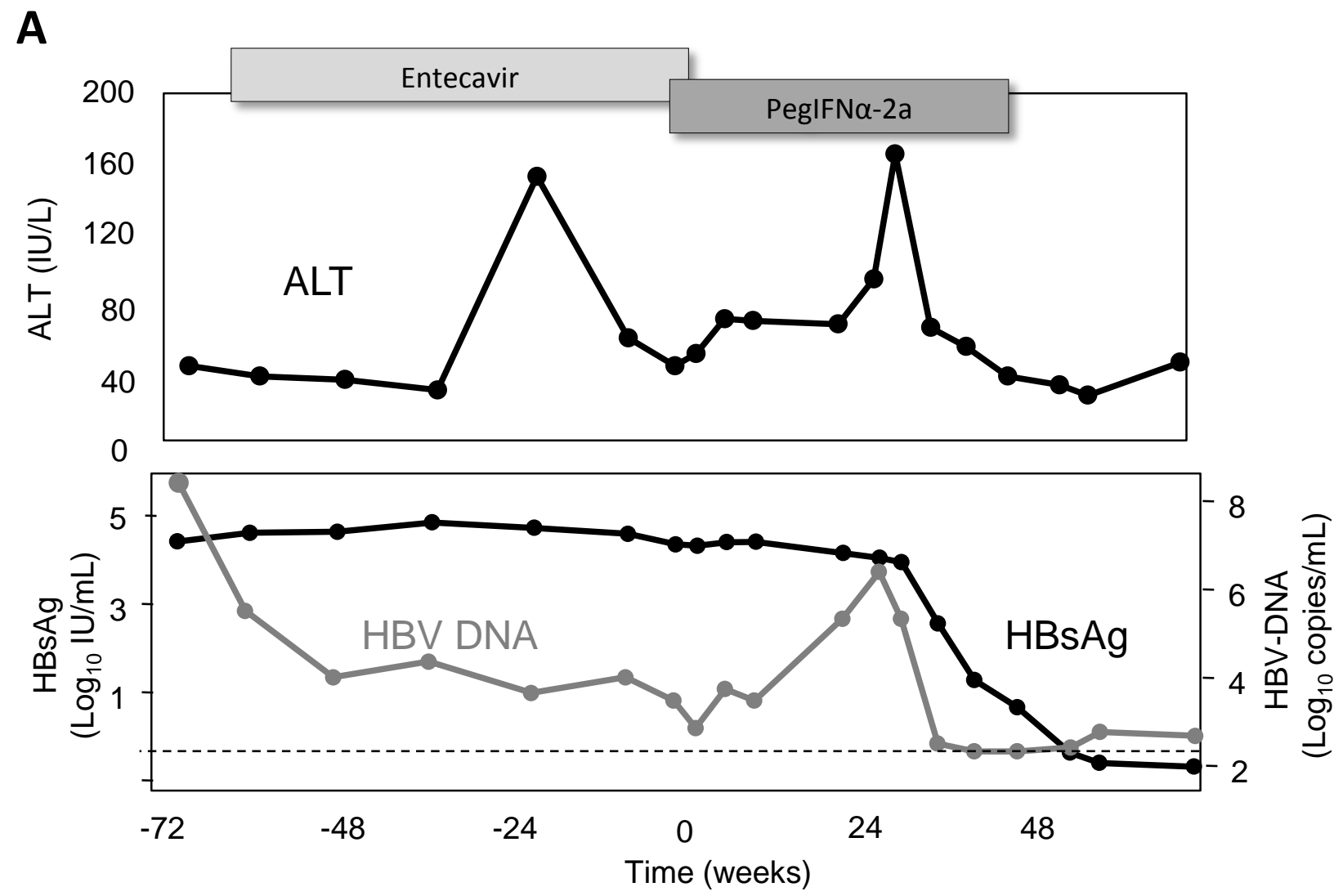

B
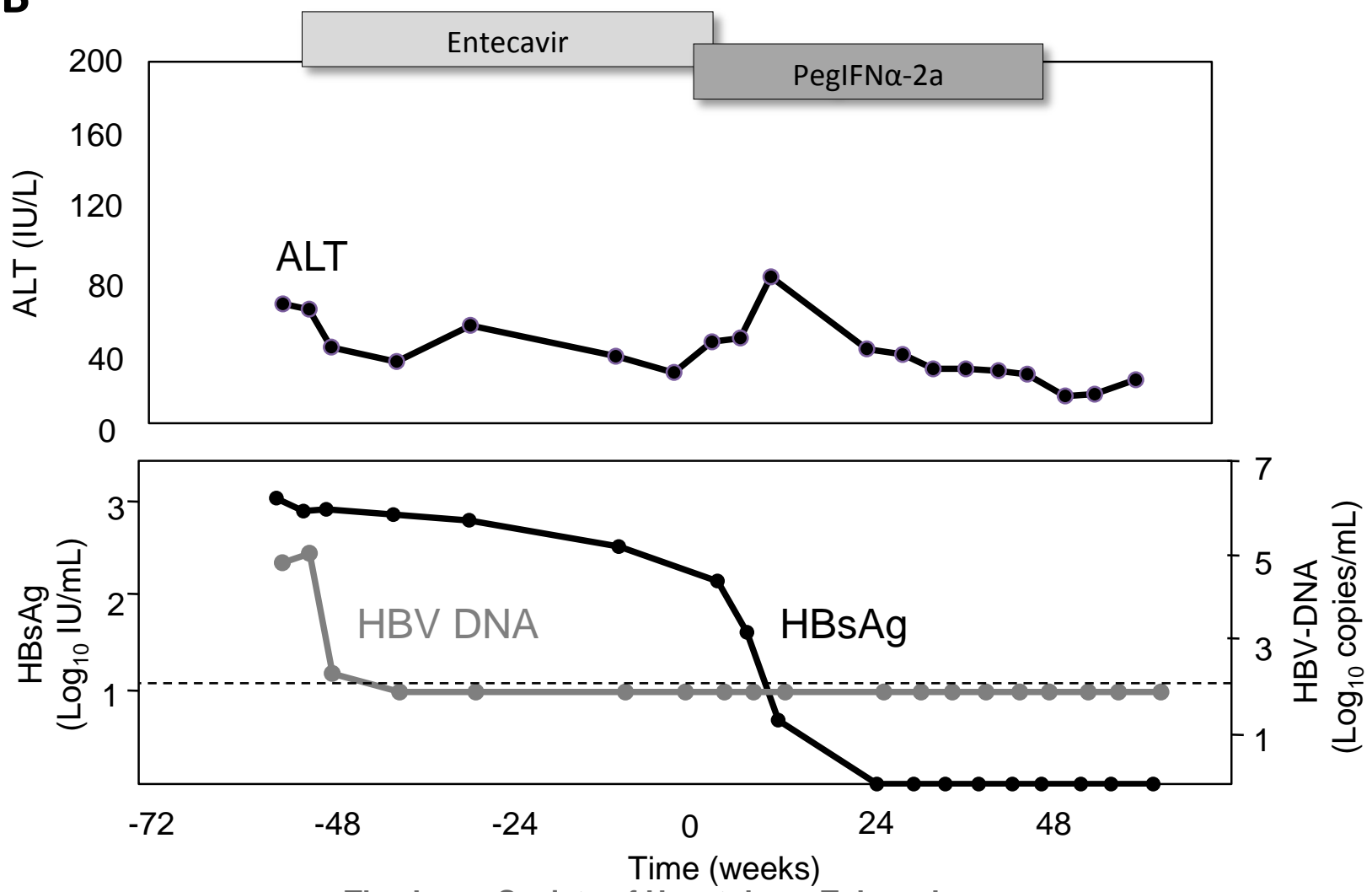

The Japan Society of Hepatology, Tokyo, Japan 